\title{
The Difference of Satisfaction Level of Midwifery Students in Trying Out Competency Test with Computer-Based Test and Web-Based Test
}

\author{
Rachmi Nurul Hidayat Hafid \\ Midwifery Studies Program, Post Graduate School, Hasanuddin University, Indonesia \\ Corresponding Email: hafidrnh19p@student.unhas.ac.id

\section{Yusring Sanusi Baso} \\ Learning Media Center, Learning Resources and E-Learning, Hasanuddin University, Indonesia \\ Email: yusring@unhas.ac.id
}

\author{
Sri Ramadany \\ Faculty of Medicine, Hasanuddin University, Indonesia \\ Email: sriramadanifk@gmail.com \\ Esther Sanda Manapa \\ Graduate School, Hasanuddin University, Indonesia \\ Email: esmanapa@gmail.com \\ Muhammad Tamar \\ Faculty of Medicine, Hasanuddin University, Indonesia \\ Email:muh.tamar@unhas.ac.id
}

\begin{abstract}
This study aims to find out the difference in satisfaction level to try out competency test (UKOM) with the computer-based test and web-based test. Research method using research and development $(R \& D)$ and preexperimental with one group pre and post-test design using purposive sampling techniques. The data were analyzed with the Wilcoxon test. This research was conducted at the Polytechnic of Health Ministry of Makassar and Megarezky Makassar University in November 2020. The results: it's necessary to design an application for midwifery students, the design was made attractive and complete, validation results from 2 media experts averaged $87.9 \%$ and 2 material experts $94 \%$ who showed that the application is very feasible to use as well as 10 user trials with an average value of $95.1 \%$. The satisfaction levels of tryout UKOM computer-based test by 45 users was $72.1 \%$ after given an intervention by $88.6 \%$, so student's satisfaction levels increased by $17,2 \%$ and the statistical test found a p-value of $0.000<0.05$. So it can be concluded that there is a difference in the level of satisfaction of midwifery students to try out UKOM with computer-based test and web-based test.
\end{abstract}

Keywords---midwifery, satisfaction, TAM, try out UKOM, web-based test application.

\section{Introduction}

Competency test (UKOM) is a benchmark of knowledge, skills, and attitudes owned by students in universities that organize higher education in the field of health (Bartram et al., 2002; Bartram, 2005; Wesselink \& Wals, 2011; Kemenristekdikti, 2016). UKOM becomes a requirement to get a registration letter (STR) as the main capital of midwives in providing professional health services (Kemenkes, 2013). However, the percentage of UKOM graduations for the last two years, namely 2018 and 2019 is still very far from the national graduation expectations. 
(Kemenristekdikti, 2020). Regional Coordinator of the Indonesian Midwifery Education Association (AIPKIND) of South Sulawesi and West Sulawesi stated that the percentage of UKOM graduations for sixty midwifery education institutions is still very low at $14.26 \%$ in 2018 and 33.76\% in 2019 (Regional Coordinator of the Indonesian Midwifery Education Association (AIPKIND) Of South Sulawesi, 2020).

The institution affects the passing rate of students in the competency test (Mushawwir et al., 2020). Many strategies are emerging to prepare students to take competency tests, among others are online caching, nursing clinic courses, remedial policies, preparation competency test courses, course work, and adaptive quizzing system tests, the educational basic curriculum establishment, learning methods, etc. One of the strategies is by tryout method.

Since April 2020, the government has officially announced that Indonesia has been hit by non-natural coronavirus disease 2019 (COVID-19) as a national disaster (President, 2020). This condition requires all academic processes to be done by online methods from home and utilizing all information technologies, one of which is webbased learning by utilizing the words wide web platform (Dodd, 2012; Prasetya, 2015; Chiu \& Wang, 2008). This is a challenge for educational institutions and lecturers to still be able to conduct try out UKOM online.

Regularly try out will help students to obtain good graduation grades to increase satisfaction with learning outcomes. Measurement of satisfaction level can be objective feedback in the development of learning media to be more effective and efficient. The level of student satisfaction in following the process will affect the learning outcomes (Ginaya et al., 2020; Dochy et al., 2003; Pedaste et al., 2015). Previous research related to the web-based midwifery try-out UKOM application suggests that the application still feels heavy requires a long loading time and cannot be carried out online (Maulana et al., 2018; Harvey et al., 2002; Pallant et al., 2015). Based on the description above, it is necessary to develop a try-out UKOM web-based test application and after the application is created it can be compared to the level of satisfaction of students who follow the try-out UKOM with computer-based test and web-based test.

\section{Research Methods}

Research has two stages, namely developing try-out UKOM web-based test application using the research and development (R \& D) method of Borg and Gall model and assessing the level of satisfaction of the application using the pre-experimental method with one group pretest and posttest design. The R\&D method begins with a needs analysis through preliminary studies involving lecturers and midwifery students. Then, design development, material development, questions, and instruments are carried out. After the initial draft of the application is completed, validation is carried out by 2 media experts, 2 material experts, and 10 midwifery students as users to assess the feasibility of the application. Furthermore, a user satisfaction level assessment involving 45 midwifery students using purposive sampling techniques was carried out. User satisfaction is measured before and after being given the tryout UKOM web-based test application. The data were analyzed using the normality test and Wilcoxon Sign Rank Test statistics. This research was conducted at the Health Polytechnic Ministry of Health Makassar and the Megarezky Makassar University of South Sulawesi in November 2020.

\section{Results}

\section{Product analysis developed}

There need to be more innovative media to facilitate lecturers and students to doing try out UKOM where and whenever, especially during the COVID-19 pandemic with menu servings made as closely as possible to the real UKOM.

\section{Initial product development}

The initial draft of the application consists of design, UKOM questions, discussions, answer keys, scientific journals, midwifery guidelines, and research instruments. 


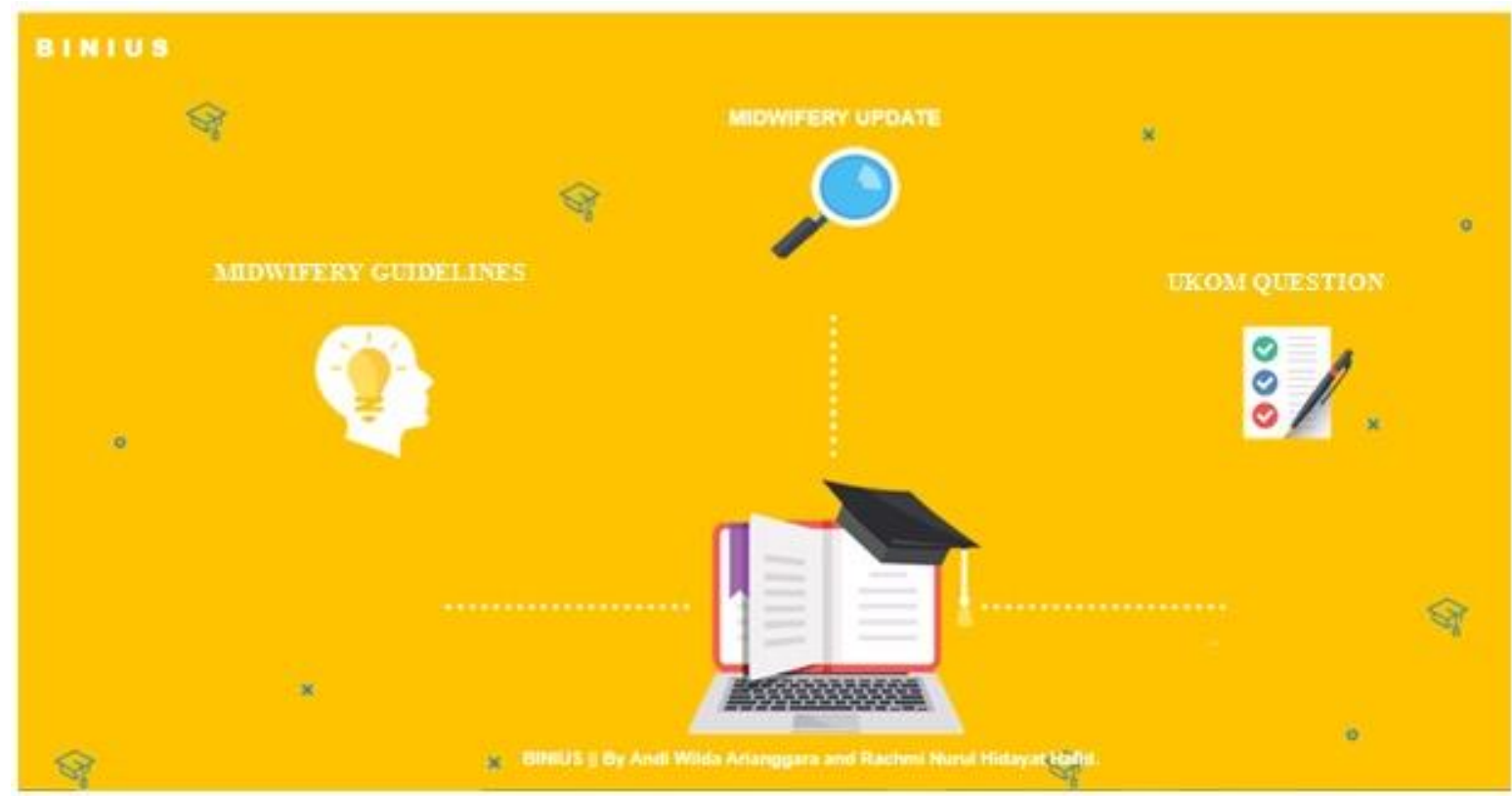

Figure 1. Home page view

Expert Validation Test

Table 1

Material expert validation results

\begin{tabular}{|c|c|c|c|}
\hline Assessment Aspects & Expert I & Expert II & Average Rating \\
\hline Content & 100 & 97,5 & $\mathbf{9 8 , 7}$ \\
\hline $\begin{array}{l}\text { The relevance of the material too basic } \\
\text { competencies }\end{array}$ & 5 & 5 & \\
\hline Systematics of problem presentation & 5 & 5 & \\
\hline Clarity of description of the problem & 5 & 5 & \\
\hline Accuracy of the material & 5 & 5 & \\
\hline Accuracy of terms used & 5 & 5 & \\
\hline Accuracy of problem illustrations & 5 & 5 & \\
\hline $\begin{array}{l}\text { Suitability of presentation of the question with } \\
\text { the rules of writing the question }\end{array}$ & 5 & 5 & \\
\hline $\begin{array}{l}\text { Adequacy of providing feedback on learning } \\
\text { motivation }\end{array}$ & 5 & 4 & \\
\hline Serving & 100 & 75 & 87,5 \\
\hline $\begin{array}{l}\text { Presentation of questions according to } \\
\text { proportions }\end{array}$ & 5 & 5 & \\
\hline Clarity of exam implementation instructions & 5 & 3 & \\
\hline $\begin{array}{l}\text { Suitability of instruction with the } \\
\text { implementation of the exam }\end{array}$ & 5 & 3 & \\
\hline $\begin{array}{l}\text { The effectiveness of time in answering } \\
\text { questions }\end{array}$ & 5 & 4 & \\
\hline Language & 100 & 93,3 & 96,6 \\
\hline Structural accuracy of sentences & 5 & 4 & \\
\hline Effectiveness of sentences & 5 & 5 & \\
\hline The rigor of The Term & 5 & 5 & \\
\hline Grammatical accuracy & 5 & 5 & \\
\hline Spelling accuracy & 5 & 5 & \\
\hline Language conformity with education level & 5 & 4 & \\
\hline
\end{tabular}


Contextual

Compatibility between the application and the actual competency test situation

Conformity with the curriculum

Reflecting on the competencies to be achieved
100

5

86,6

4

5

$5 \quad 4$

$100 \quad 88,1$

5

88,1
93,3

94

Table 2

Media expert validation results

\begin{tabular}{lccc}
\hline Assessment Aspects & Expert I & Expert II & $\begin{array}{c}\text { Percentage } \\
\text { Assessment (\%) }\end{array}$ \\
\hline Display & $\mathbf{9 0}$ & $\mathbf{8 5 , 4}$ & $\mathbf{8 7 , 7}$ \\
Clarity of instructions for use of the program & 4 & 3 & \\
Limitations of text or writing & 5 & 4 & \\
Accuracy of color selection and composition & 4 & 4 & \\
Placement consistency & 5 & 4 & \\
Image display quality & 4 & 4 & \\
Image feed & 5 & 5 & \\
Layer view & 5 & 5 & \\
Accuracy of language usage & 5 & 4 & \\
Background color with text & 4 & 5 & \\
App size & 4 & 4 & \\
Loading time speed & 5 & 5 & \\
Programming & $\mathbf{9 7 , 5}$ & $\mathbf{7 5}$ & \\
Navigation clarity & 5 & 3 & \\
Consistency of key usage & 5 & 4 & \\
Ease of use & 4 & 4 & \\
Text efficiency & 5 & 4 & \\
Image efficiency & 5 & 4 & \\
Response to learners & 5 & 3 & \\
Media affairs & 5 & 4 & \\
Easy to choose a serving menu & 5 & 4 & \\
Media presentation & $\mathbf{1 0 0}$ & $\mathbf{8 0}$ & \\
Attractive and easy to carry or move & 5 & 4 & \\
Media presentation can develop a learning & 5 & 3 & \\
interest & & & \\
Given media title or caption & 5 & 5 & \\
\hline & $\mathbf{9 5 , 8}$ & $\mathbf{8 0 , 1}$ & \\
\hline
\end{tabular}

Small scale field trials

Table 3

Results of small-scale field trials

\begin{tabular}{lc}
\hline Components & Average Value \\
\hline Perceived ease to use & 4,92 \\
Perceived usefulness & 4,9 \\
Attitude toward & 4,85 \\
Behavioral intention & 4,74 \\
Actual usage & 4,37 \\
\hline Average & $\mathbf{4 , 7 5}$ \\
\hline
\end{tabular}


The results of the application's small-scale field trial showed that of the five components obtained a value above 4.75 $(95.1 \%)$ with very decent criteria.

Large scale field trials

Table 4

Student satisfaction level category

\begin{tabular}{lcccc}
\hline \multirow{2}{*}{ Satisfaction Level } & \multicolumn{2}{c}{ Computer Based Test } & \multicolumn{2}{c}{ Web-Based Test } \\
\cline { 2 - 5 } & Frequency & Percentage & Frequency & Percentage \\
\hline Very satisfied & 0 & 0 & 43 & 95,6 \\
Satisfied & 40 & 88,9 & 2 & 4,4 \\
Quite satisfied & 2 & 4,4 & 0 & 0 \\
Dissatisfied & 3 & 6,7 & 0 & 0 \\
Very dissatisfied & 0 & 0 & 0 & 0 \\
\hline Total & 45 & 100 & 45 & 100 \\
\hline
\end{tabular}

Table 5

Results of pretest and posttest of each item satisfaction level

\begin{tabular}{lcccccc}
\hline \multirow{3}{*}{ Data } & \multicolumn{5}{c}{ Item Satisfaction Level } & \multirow{2}{*}{ Average } \\
\cline { 2 - 6 } & Tangible & Reliability & Responsiveness & Assurance & Emphaty & \\
\cline { 2 - 6 } & Value (\%) & Value (\%) & Value (\%) & Value (\%) & Value (\%) & 72,1 \\
Computer based test & 77,3 & 70,2 & 71,5 & 70,6 & 70,9 & \\
Web based test & 88 & 88,1 & 87,1 & 87,6 & 92 & 88,5 \\
\hline
\end{tabular}

Table 6

Satisfaction level test results

\begin{tabular}{lccc}
\hline Data & Median & Minimum - maximum & $\rho$-value \\
\hline Computer based test $(\mathrm{n}=45)$ & 45 & $36-47$ & 0,000 \\
Web based test $(\mathrm{n}=45)$ & 53 & $46-60$ & \multirow{2}{*}{. } \\
\hline
\end{tabular}

\section{Discussion}

Based on the table of expert validation test results, try out UKOM web-based test application is considered very feasible and provides an attractive look so that it can motivate students to learn and answer questions. This is following the results of research that mentions the attractive display of e-Learning can increase interest and motivation of learning so that the learning atmosphere becomes active learning (Prasetya, 2015). Assessment of small scale field trials of applications with technology acceptance model (TAM) components that include perceived ease to use, perceived usefulness, attitude toward, behavioral intention, and actual usage with very decent categories. Some research states that user acceptance of information technology innovation is done by TAM analysis because the user's intention to use the new information system can be influenced by the perception of whether a system will be useful and easy to use (Udayanti \& Nugroho, 2018; Ammenwerth, 2019).

The level of student satisfaction has increased 16, 4\%, namely from being quite satisfied to be very satisfied. The factor that influences this is the menu presented on the try out UKOM web-based test application with a more complete and interesting. These results are supported by several studies suggesting that web-based media is better in terms of flexibility and time efficiency than computer-based media with specific servers (Priyambodo \& Antuni, 2017). Web-based learning or evaluation media also has high effectiveness as a support in achieving student competencies because it can facilitate the learning process indefinitely and place (Sari \& Suswanto, 2017; Van den Boom et al., 2004).

Statistical test against trying out UKOM computer-based test and web-based test results obtained Wilcoxon Sign Rank test with $\rho$-value of $0.000<0.05$ then it can be concluded that there is a difference in the level of satisfaction of 
midwifery students to try out UKOM with computer-based test and web-based test. The expected implication of tryout the UKOM web-based test application is to facilitate students and lecturers to implement try out UKOM independently, flexibly, and efficiently.

\section{Conclusion}

Try out UKOM web-based test application is very feasible to use and can increase the level of student satisfaction. Based on the statistical test, there is a difference in the level of satisfaction of midwifery students to try out UKOM with computer-based tests and web-based tests.

\section{Acknowledgments}

We thank the mentors who have taken their time in the preparation of this research and to our parents who always pray for the researchers to finish. We also thank the Health Polytechnic Ministry of Health Makassar and Megarezky Makassar University for the support and assistance provided during our research and special appreciation to all study participants who volunteered for this research.

\section{References}

Ammenwerth, E. (2019). Technology Acceptance Models in Health Informatics: TAM and UTAUT. Studies in health technology and informatics, 263, 64-71.

Bartram, D. (2005). The Great Eight competencies: a criterion-centric approach to validation. Journal of applied psychology, 90(6), 1185.

Bartram, D., Robertson, I. T., \& Callinan, M. (2002). Introduction: A framework for examining organizational effectiveness. Organizational effectiveness: The role of psychology, 1-10.

Chiu, C. M., \& Wang, E. T. (2008). Understanding Web-based learning continuance intention: The role of subjective task value. Information \& Management, 45(3), 194-201. https://doi.org/10.1016/j.im.2008.02.003

Dochy, F., Segers, M., Van den Bossche, P., \& Gijbels, D. (2003). Effects of problem-based learning: A metaanalysis. Learning and instruction, 13(5), 533-568. https://doi.org/10.1016/S0959-4752(02)00025-7

Dodd, A. Z. (2012) Praise Essential Guide to Telecommunications. Fifth Edit. United States of America: Prentice Hall.

Ginaya, G., Kanca, I. N., \& Astuti, N. N. S. (2020). Designing problem-based learning (PBL) model for tourism vocational education in $4 . \mathrm{O}$ industry. International journal of linguistics, literature and culture, 6(1), 14-23.

Harvey, S., Rach, D., Stainton, M. C., Jarrell, J., \& Brant, R. (2002). Evaluation of satisfaction with midwifery care. Midwifery, 18(4), 260-267. https://doi.org/10.1054/midw.2002.0317

Kemenristekdikti. (2016). Regulation of the Minister of Research, Technology, and Higher Education of the Republic of Indonesia Number 12 of 2016 Tetang Procedure for Implementation of Student Competency Test in health sector. Minister of Research, Technology and Higher Education of the Republic of Indonesia, pp. 1-7.

Kemenristekdikti. (2020). No Title, Online Registration D3 Midwifery Competency Test.

Maulana, M. S., Khairuzzaman, M. Q., \& Nasihin, M. (2018). Intranet-Based Midwifery Competency Test Web Application. Journal of Education and Informatics Research (JEPIN), 4(2), 156-162.

Ministry of Health (2013) 'Regulation of the Minister of Health of the Republic of Indonesia Number 46 Year 2013 concerning Registration of Health Workers', Minister of Health of the Republic of Indonesia, pp. 1-18.

Mushawwir, A., Tahir, T., Kadar, K., \& Saragih, S. L. (2020). Evaluate the Implementation of Educational Curriculum and Lecturer's Knowledge About the Blueprint to the UKNI's Graduation Rate in South Sulawesi. Int. J. Psychosoc. Rehabil, 24(08), 14709-14719.

Mushawwir, A., Tahir, T., Kadar, K., Ahmar, H., \& Khalid, N. (2019). Gambaran Strategi Program Studi Keperawatan Untuk Meningkatkan Kelulusan Mahasiswa Dalam Uji Kompetensi: Literatur Review. Jurnal Keperawatan Muhammadiyah, 4(2).

Pallant, J. F., Dixon, L., Sidebotham, M., \& Fenwick, J. (2015). Further validation of the perceptions of empowerment in midwifery scale. Midwifery, 31(10), 941-945. https://doi.org/10.1016/j.midw.2015.05.008

Pedaste, M., Mäeots, M., Siiman, L. A., De Jong, T., Van Riesen, S. A., Kamp, E. T., ... \& Tsourlidaki, E. (2015). Phases of inquiry-based learning: Definitions and the inquiry cycle. Educational research review, 14, 47-61. https://doi.org/10.1016/j.edurev.2015.02.003

Prasetya, M. A. (2015). E-Learning Sebagai Sebuah Inovasi Metode Active Learning. Edukasia: Jurnal Penelitian Pendidikan Islam, 10(2). 
President, R. I. (2020). Presidential Decree No. 12 of 2020 concerning Determination of Non-Natural Disasters of Corona Virus Disease 2019 (Covid-19) As a National Disaster', President of the Republic of Indonesia, (01), pp. $1-3$.

Priyambodo, E., \& Antuni, W. (2017). The Influence of Web-Based Interactive Learning Media on Student Learning Motivation. 42, 99-109.

Regional Coordinator of the Indonesian Midwifery Education Association (AIPKIND) Sulselbar. (2020). Recap of Midwifery Competency Test Results. Makassar, pp. 1-8.

Sari, HV, \& Suswanto, H. (2017). Development of web-based learning media to measure student learning outcomes in the basic computer network subject of computer and network engineering expertise program. Journal of Education: Theory, Research, and Development, 2 (7), 1008-1016.

Udayanti, ED, \& Nugroho, FA (2018). Analysis of Interest in Using the TB eScoring Application with the Technology Acceptance Model (TAM) Approach. Edu Komputika Journal, 5 (1), 1-12.

Van den Boom, G., Paas, F., Van Merrienboer, J. J., \& Van Gog, T. (2004). Reflection prompts and tutor feedback in a web-based learning environment: Effects on students' self-regulated learning competence. Computers in Human Behavior, 20(4), 551-567. https://doi.org/10.1016/j.chb.2003.10.001

Wesselink, R., \& Wals, A. E. (2011). Developing competence profiles for educators in environmental education organisations in the Netherlands. Environmental Education Research, 17(1), 69-90. 